\title{
SCHOOL PROBLEMS IN THE EDUCATION AND DEVELOPMENT OF GIFTED CHILDREN: PSYCHOLOGICAL ASPECT
}

\author{
Gulnara F. Gali*, Bulat I. Fakhrutdinov, Irina Z. Shakhnina, Elena N. Zagladina \\ Candidate of Pedagogic Sciences, Kazan Federal University, Kazan, Russia. \\ Email: "gulnaragali@mail.ru
}

Article History: Received on $15^{\text {th }}$ July 2019, Revised on 30 ${ }^{\text {th }}$ August 2019, Published on $18^{\text {th }}$ September 2019

\begin{abstract}
Purpose of the Study: The urgency of the problem under investigation is because, the issue of gifted students' education is one of the most difficult and interesting aspects of contemporary pedagogy. The purpose of the article is to identify the psychological characteristics of the gifted students' development. In this article, the school difficulties of gifted students are revealed and the causes of internal and external nature are analyzed.
\end{abstract}

Methodology: The leading approach to the study of this problem is a method of a theoretical analysis and synthesis of social, political, and psycho-pedagogical literature.

Results: The main result of the study is a theoretical analysis of the relationship between learning and the development of gifted children and their psychological characteristics.

Application: The materials of the article can be useful for teachers, students, and a wide range of readers interested in the problems of gifted students' education. The authors pay special attention to the social and emotional consequences, which can be rather destructive if appropriate assistance is not provided by teachers, psychologists, and parents.

Keywords: Education, Learning, Development, Gifted Students, Problems, Difficulties, Psychological Characteristics.

\section{INTRODUCTION}

The study of the psychology of giftedness, as well as the identification and training of gifted students acquired particular importance at the beginning of the $21^{\text {st }}$ century. This problem affected many countries, such as the USA, Great Britain, Germany, France, Israel, Japan, etc. Today, the education system has a special responsibility to support gifted students not only to maximize the capabilities of the gifted, but also to use their intelligence and abilities, without prejudice to the development of their psyche and mental health. According to many domestic and foreign researchers, we also consider that for all students, the goal of education and upbringing is to provide conditions for the disclosure and development of their abilities with a view to the subsequent implementation in professional activities (McMann \& Oliver, 1988; Davis \& Rimm, 2004; Ratner, 2009).

During our research, we have revealed a number of problems and difficulties that gifted children experience as a result of their exceptional abilities: difficulties in dealing with peers; unrealistic assessment of their abilities; perfectionism; dyssynchrony, reflected in a marked discrepancy between their high potential and the difficulties of its practical implementation between the pace of progress of the intellectual, affective, and motor spheres; pressure from parents and teachers; inflexibility of the curriculum; low motivation for reproductive activity; lack of effective teaching style; school failure; conflict between individual psychological needs of a gifted student and lack of opportunities for appropriate training; problems of psychosocial nature (highly developed sense of justice, personal value system, vivid imagination, developed sense of humor, exaggeration of fears, and easy vulnerability) (Gali, Shakhnina, Zagladina, Belyaeva, Dulmukhametova, \& Ibragimova, 2018).

It should be noted that it is the psychological characteristics of the gifted students that play an important role in the understanding of the main objectives of training and education. The analysis of foreign literature reveals that teachers face serious problems at the initial stage of training. Not always a gifted student has a high academic performance. On the contrary, according to B. Clark, their advanced development can cause problems in learning, cognitive and personal development, communication, and behavior (Clark, 2008). This occurs as a result of the lack of special educational conditions for the gifted, since their high cognitive abilities and needs often do not find a response in a traditional school focused mainly on age (Reis \& Renzulli, 1991; Clark, 1992). In this regard, it is important to note that about $30 \%$ of those who were dismissed from school for their inability and failure were gifted children. Taking into account the statistics of recent years, 55\% of New York City's gifted students did not fit the high level of their cognitive abilities, and $19 \%$ of senior pupils who were dismissed for academic failure were gifted. Later, it was revealed that the number of 
gifted adolescents among those who were dismissed for academic failure reached $15-30 \%$ in different states. Similar facts were published in Canada, Germany, Hungary, Israel, etc (Callahan, 2001).

In this connection, the article aims to answer the questions: "What are the causes of school difficulties for gifted children? Why are their high abilities not materialized at school?

To investigate this problem, the authors' used methods of a theoretical analysis and synthesis of social, political and psycho-pedagogical literature.

Taking into consideration international experience, the authors analyze the school difficulties of gifted students.

\section{METHODS}

The objects of our investigation are: 1) to define the psychological problems of gifted children; 2) to determine the current requirements for work with gifted students; 3) to study the international experience of working with gifted students to enhance the effectiveness of gifted students' education.

For confirmation of the hypothesis we need to turn to a variety of methods:

- Historical and logical analysis of regulatory documents of foreign governments and research papers by leading scientists connected with educational issues of gifted students' education;

- Theoretical analysis and synthesis of social, political, and psycho-pedagogical literature;

- Analysis, comparison, synthesis, and generalization of innovative foreign and domestic pedagogical experience;

- Comparison of data of foreign and domestic research on this issue.

The fundamental works of foreign and Russian scientists in the field of pedagogy and psychology (Frimen, Parker, Renzulli, Torrens, Andreev, Bogoyavlenskaya, Leytes, Matyushkin, Panov, Savenkov, Ratner, etc.) were the theoretical basis of the study.

The usage of the methodology and methods of existing research contributes to the development of scientific thought in education for gifted students. It provides the opportunity to comprehensively address the problem of gifted students' education.

\section{RESULTS}

The analysis of domestic and foreign literature shows that the difficulty of this problem is because, more than 50\% of practitioners have only superficial ideas about what problems gifted students face. For effective work with gifted students, the analysis and identification of genuine mechanisms causing these problems are needed, and an understanding that giftedness is not just the result of a child's high abilities, but, firstly, the problem of the development of his or her personality (Vialle \& Quigley, 2002; Mendaglio \& Peterson, 2007).

It is important to note that the failures of gifted schoolchildren in education are generated by a complex interlacing of various causes, both internal and external. Among such reasons, psychologists distinguish the influence of socioeconomic and national-cultural conditions. Gifted students from families with low economic status and an unfavorable socio-cultural environment are usually facing these problems. In some countries, the development of gifted girls can be strongly influenced by national and cultural stereotypes of the environment (Maklakova, Khovanskaya, \& Gubaydullina, 2017).

The next problem is that gifted children, getting into school communities, where most of their peers have average abilities, feel obvious or hidden ill-will and distrust of other children. As a result, gifted students do not want to stand out and look like a "black sheep". That is why their creative abilities are gradually leveled (Fakhrutdinova, Fakhrutdinova, \& Severyanov, 2013).

Also, it is necessary to mention the social and emotional consequences, which can be quite destructive if there is no assistance from teachers, psychologists, and parents. As it was mentioned by many researchers, gifted students with a disharmonious type of development have problems in emotional development. Most of them are characterized by increased sensitivity. As a result, children are most responsible for the results of their activities. They think that it is the cause of success and failure, which lies in them and leads to an unreasonable sense of being guilty, self-flagellation, and sometimes to depressive states.

There are also problems in gifted children's education with physical limitations, but at the same time, it must be emphasized that often serious physical defects are a strong motivation to higher achievements. 
Furthermore, there are school problems for children with high creative abilities. Creative energy, which dominates in the life of such children, determines the independence and non-standard behavior of these children. Their behavior may be considered by teachers as undisciplined. Frequent confrontation with the environment requires them to learn either to cope with the rising tension or to suppress their creative needs and try to be "like everyone else", which can lead to personal destruction, aggression or apathy. Accordingly, it is difficult to expect a high motivation of gifted children for learning and notable successes in this situation (DeVries, 2007).

Also perfectionism is of great interest. This term is used to refer to both a healthy desire for excellence, which contributes to the achievement of professional excellence, and neurotic, obsessive achievement of a certain ideal on change of high demands into a painful dissatisfaction with the results of work, which negatively affects the creative process. This phenomenon is especially manifested in gifted people. Perfectionism, on one hand, can serve as a source of failures for gifted students, when established standards are not achieved, but, on the other hand, it can also provide a positive motivation for their self-improvement, since it serves as an internal stimulus for progress in development (Zeigler \& Raul, 2000).

The other problem is that gifted children are not properly understood, especially in the early stages of their development even by their parents. Sometimes the parents' reaction to the active cognitive abilities of their child could be qualified as strange and sometimes even negative. Very often, parents do not want to treat their child as something special (Gubaidullina \& Hakimzyanova, 2014). Active creative abilities are combined with increased neuropsychic excitability, which could be marked by different factors - number of disorders in appetite, sleep, and behavior. Also, there appear such symptoms as rising headaches, restlessness, etc. Untimely medical and psychological correction of these symptoms leads to the development of neuroses and other psychosomatic diseases.

Besides, there is another special group of gifted students who have difficulties in mastering basic skills of reading, writing, counting, studying native or foreign language, or other areas of knowledge. These children are called 'Gifted Learning Disabled', although their development is normal (Brody \& Mills, 2007). The following features of the lack of ability to learn are highlighted:

- Brilliant long-term memory can be combined with the weakness of short-term memory, therefore, it is often difficult for them to repeat what has just been said;

- Gifted students can easily master a computer, but they cannot learn to write legibly, which affects the results of written work;

- Many gifted children do much better with complex tasks, but routine activities, simple memorization, repetition exercises are performed by them with difficulty;

- Gifted students can be very disorganized and inconsiderate, therefore they are incapable of performing time-limited tasks (tests) (Parker \& Adkins, 2005).

The problems in learning are often the result of the uneven psychological and social development of gifted children. The unevenness in the development of the gifted, reflected in a noticeable imbalance between their high potential and the difficulties of its practical realization, between the pace of progress of the intellectual, affective, and motor spheres, was called dyssynchrony. J. Terrasier considers dyssynchrony in two interrelated aspects: the internal aspect reflects a partial imbalance in the development of giftedness in different areas; and external or social aspect, which expresses the child's connections with the outside world (Terrasier, 1985).

One of the most important manifestations of internal dyssynchrony is the contradiction between intellectual and psychomotor development. It is quite well known that psychomotor giftedness is often combined with the underdevelopment of the intellectual sphere of a child, adolescent or adult. Hours of practice and training, lack of free time, severe physical exhaustion of talented athletes do not contribute to the development of their intellectuality.

The following example of dyssynchrony can be considered as a poor knowledge of the writing skills of students who are gifted in the intellectual sphere. According to many researchers, this is due to differences in the speed of intellectual and psychomotor processes of these children. Insufficiently formed written speech contradicts the rapid pace of cognitive activity, which often leads to the fact that the child is trying to get rid of this kind of disharmony. Accordingly, this can lead to a decrease in the pace of intellectual action on one hand, and to a noticeable deterioration in the quality of the writing, numerous errors, and inaccuracy on the other hand. Gifted students often have an imbalance between the development of verbal, visual-figurative, and visual-efficient thinking. There is also an inadequate development of the system of attention regulation. Gifted children are distracted, bored, trying to entertain themselves if they are not interested, but, at the same time, can be attentive and focused when they are passionate about the task. 
Speaking about the problem of giftedness, it is also necessary to mention the social and emotional consequences that can be quite destructive if there is no help from teachers, psychologists, and parents. Often, gifted students with a disharmonious type of development have problems in emotional development. Most of them have increased susceptibility and sensitivity. For example, these children are characterized by taking responsibility for the results of their activities. They think that they are responsible for successes and failures and they have unreasonable feelings of guilt, self-flagellation, and sometimes depressive states (Lovecky, 1992).

In the field of psychosocial development, the following aspects are revealed:

"A strongly developed sense of justice;

The presence of a personal value system;

Vivid imagination;

A developed sense of humor;

Tendency to exaggerate fear;

The ability to extrasensory perception;

The ability to understand and feel without any explanations;

Easy vulnerability" (Ratner, 2009).

In addition to the problems of diagnosis, education, and development of gifted students, it is necessary to emphasize the problem of preparing teachers to work with them. According to the research data, children with high intelligence most need their "own" teacher. Clearly, teachers working with such children should have special training and the main components of the teacher's professional qualifications for working with gifted students are psychological and pedagogical knowledge, skills, and technologies on one hand, and professional and personal qualities of the teacher on the other hand (Gali, 2011).

\section{DISCUSSION}

The basic reason to make a detailed analysis of pedagogical conditions for gifted students' development and education is the specificity of gifted education. The research has shown that the problem is considered as one of the most important in the world. Of course, the special teacher training, i.e. professional and personal qualifications of teachers contribute to the effective solution of the problem of gifted students' education and development. The psychological characteristics of the gifted students play an important role in understanding the main objectives of training and education. Several problems and difficulties that gifted children experience as a result of their exceptional abilities are revealed.

Various aspects of the problem of gifted students' development and education are reflected in the scientific work of foreign researchers: Whitemore (2012), Kagan (2011), Passow (2009), Renzulli (1982), and others. This problem was also considered by Russian researchers: Andreev (2010), Ratner (2009), Wolfson (2003), Panov (2003), Savenkov (2000), Dzhurinskiy (1999), and others. However, analysis of scientific papers on this issue showed us that this problem is not sufficiently considered.

\section{SUMMARY}

In the course of investigating of this problem, the authors came to the following conclusions:

1. In modern pedagogical science and educational practice, the teaching and education of gifted students are often regarded as a global pedagogical task. Foreign countries have accumulated extensive experience in working with gifted students. The effective solution of the task of identifying, developing, and educating gifted students is, of course, facilitated by special teacher training.

2. Prioritizing strategies for the teachers' activity with gifted students are the identification, application of effective forms and methods of teaching, the development of creative and leadership abilities, the creation of conditions for the development of talented students' abilities to socialize, and the effective realization of their increased opportunities in mature professional activity.

3. Gifted students are at high risk of social exclusion and have difficulty in communicating with their peers. This problem must be solved taking into account specific socio-psychological circumstances. It is necessary to unite the efforts of all participants in the educational process (psychologist, teacher, and parents).

4. Detailed study of the foreign teachers' experience with gifted students helps to improve the effect on the teaching process, education, and development of gifted students. 
The research does not exhaust all the questions connected with the study of the theory and teaching practice and psychological problems of gifted children. It should be concentrated on developing gifted students and teacher training to work with them, which could be said as perspective for further study in this field.

\section{CONCLUSION}

All mentioned above allows us to conclude that working with gifted students is multifaceted. It requires further research. Gifted children have difficulty with finding friends who are close in spirit, they have problems of participating in peer games that they are not interested in. The complexity of the situation is aggravated by the fact that the children realize that they are not similar to others.

All this allows us to conclude that it is necessary to develop effective forms and methods for preserving the intellectual and spiritual potential of the gifted students, understanding the issues of the psychological safety of the educational environment at all levels of education. It becomes obvious that the identification of gifted children must be associated with the tasks of their training and education. Consequently, the problem of identifying gifted children should be closely related to the problem of creating conditions for the intellectual and personal growth of students in schools and institutions of additional education. In our opinion, giftedness is so individual and unique that the question of the optimal conditions for the development of each child should be considered separately. Accordingly, it is very important to identify gifted children in the family and at school and create favorable conditions for the development of the personality of each child. For this, it is necessary to unite the efforts of all participants in the educational process (psychologist, teacher, and parents).

\section{ACKNOWLEDGMENT}

The work is performed according to the Russian Government Program of Competitive Growth of Kazan Federal University.

\section{BIBLIOGRAPHY}

1. Brody, L.E., \& Mills, C.J. (2007). Gifted children with learning disabilities. A review of the issues. Journal of learning disabilities, 30 (3), 282-296.

2. Callahan, C. (2001). Evaluating learner and program outcomes in gifted education. In F.A. Karnes \& S.M. Bean (Eds.), Methods and materials for teaching the gifted (pp. 253-300). Waco, TX: Prufrock Press.

3. Clark, B. (1992). Growing up gifted. New York: Macmillan.

4. Clark, B. (2008). Growing up gifted: Developing the potential of children at home and at school (7th ed.). Upper Saddle River, NJ: Pearson Prentice Hall.

5. Davis, G., \& Rimm, S. (2004). Education of the gifted and talented (5th ed.). Boston, MA: Allyn and Bacon.

6. DeVries, A.R. (2007). Gifted Parent groups: The SENG model ( $2^{\text {nd }}$ ed.). Scottsdale, AZ: Great Potential Press.

7. Fakhrutdinova, E., Fakhrutdinova, A., \& Severyanov, O. (2013). The transformation of educational approaches at the time of social and economical changes. World Applied Sciences Journal, 27 (13), 15-19.

8. Gali, G. (2011). Teacher staff preparation for work with gifted students in different countries. Kazan: Kazan University.

9. Gali, G., Shakhnina, I., Zagladina, E., Belyaeva, E., Dulmukhametova, G., \& Ibragimova, A. (2018). The Specificity of Gifted Students' Teaching: Overseas Data: Proceedings of INTCESS 2018- 5th International Conference on Education and Social Sciences, Istanbul, Turkey, 5-7 February (pp.25-31).

10. Gubaidullina, R.N., \& Hakimzyanova, A.S. (2014). Relationships between gifted children and parents. Foreign languages in the modern world: information and communication technology in the context of continuous language education materials: Proceedings of the VII International scientific-practical conference (pp. 325-332).

11. Lovecky, D. (1992). Exploring social and emotional aspects of giftedness in children. Roeper Review, 15, 1825.

12. Maklakova, N., Khovanskaya, E., \& Gubaydullina, R. (2017). Empathy As A Basic Component Of Emotional Intelligence: Proceedings of thellth International Technology, Education And Development Conference, (pp.3136-3141).

13. McMann, N., \& Oliver, R. (1988). Problems in families with gifted children: Implications for counselors. Journal of Counseling and Development, 66, 275-278.

14. Mendaglio, S., \& Peterson, J.S. (2007). Models of counseling gifted children, adolescents, and young adults. Austin, TX: Prufrock. 
15. Parker, W.D., \& Adkins, K.K. (2005). Perfectionism and the gifted. A journal on gifted education, 17 (3), $173-$ 176.

16. Ratner, F.L. (2009). The problems of personal giftedness in foreign and domestic pedagogy. Socialization of gifted schoolchildren in the context of modern social metropolitan educational space: materials of the round table (Kazan, February 2008). Kazan: RIC "School”, (pp. 22-26).

17. Reis, S.M., \& Renzulli, J.S. (1991). The assessment of creative products in programs for gifted and talented students. Gifted Child Quarterly, 35(3), 128-134.

18. Terrasier J. (1985). Ch. Dysynchrony: uneven development. The psychology of gifted children. Chichester: John Wiley\&Sons.

19. Vialle, W., \& Quigley, S. (2002). Does the teacher of the gifted need to be gifted? Gifted and Talented International, 17(2), 85-90.

20. Zeigler, A., \& Raul, T. (2000). Myth and reality: A review of empirical research studies on giftedness. High Ability Studies, 11(2), 113-136. 